\title{
Algorithm and methods of assessment the efficiency of innovative-investment projects in the field of renewable energy sources
}

\author{
I S-M Magasheva ${ }^{1, *}, D A$ Ilinykh ${ }^{2}$ and $S$ I Ultan ${ }^{2}$ \\ ${ }^{1}$ Moscow State Institute of International Relations (MGIMO University), Moscow, Russia \\ ${ }^{2}$ Dostoevsky Omsk State University, School of International Business, Omsk, Russia
}

\begin{abstract}
The article presents a universal algorithm for evaluating the efficiency of innovative-investment projects in the field of renewable energy. A comparative analysis of methods for assessment the efficiency of implementation and development of renewable energy sources described in the research studies of the Russian and foreign authors is performed. The features and main indicators of such projects are noted. The most suitable methodology in terms of feasibility of involving renewable energy sources in a particular company, was identified for Russian realities.
\end{abstract}

\section{Introduction}

The analysis of the Russian and international literature has shown that today there are no integrated and welldefined algorithms of assessment of innovativeinvestment projects in the field of implementation and development of renewable energy sources (RES) [1-11]. There is a lack of official recommendations or federal regulations to undertake such calculations. That is, there is no specifically indicated way for Russian companies that have decided to implement this type of projects to determine economic viability. Nevertheless, some authors make attempts to create an integrated algorithm and system of indicators for a particular region where the project can be implemented.

The lack of a unified systematic approach for evaluating the efficiency of RES innovative-investment projects is a serious problem for the Russian enterprises. In addition, the lack of predicted values of technical, economic, and climatic characteristics makes such estimates difficult.

Today there is no such a document that would regulate a single algorithm for the development of a feasibility study of innovative-investment projects for the implementation and/or development of renewable energy sources (regardless of the chosen methodology for assessing efficiency). So, in this work the authors attempted to draw up a universal algorithm for assessing the economic efficiency of innovative-investment projects, highlighting in a separate block a feasibility study for the implementation of renewable energy projects. The proposed algorithm is presented in figure 1 .

Since the investment component is a fundamental aspect of the RES projects we are studying, it makes sense to refer to the "Methodological Recommendations for Evaluating the Efficiency of Investment Projects", according to which the efficiency of such projects is assessed in 2 stages:

1. The financial solvency of the enterprise (financial assessment) should be determined;

2. The assessment of the economic efficiency of investment projects (economic assessment) should be carried out.

However, innovative projects are a more specific version of investment projects, which is reflected, at a minimum, in changes in possible risks from the implementation of such projects. Furthermore, such a scheme does not take into account the special technical and economic indicators of power plants along with the specific natural and climatic factors that are not inherent in traditional power plants.

Thus, in the generally accepted two-stage algorithm in Russia, we have introduced the "Technical Assessment" block, which allows us to fully evaluate the project on the use of alternative energy sources.

Particular attention in this algorithm should be given to the Feasibility Study block, since the choice of equipment and, consequently, the efficiency of the entire project depend on correctly calculated technical and environmental climatic characteristics. A technical assessment of the renewable energy investment project will help to identify the prospects and feasibility of using one or another power plant. Depending on the type of energy source selected, various indicator systems can be included in the Technical Assessment block.

In the article "The review of features of innovativeinvestment projects in the field of implementation and development of renewable energy sources and issues of evaluating their efficiency" [12] a list of the main operations that must be carried out when evaluating the economic efficiency of an innovative-investment project is outlined, namely:

Corresponding author: imagasheva95@gmail.com 


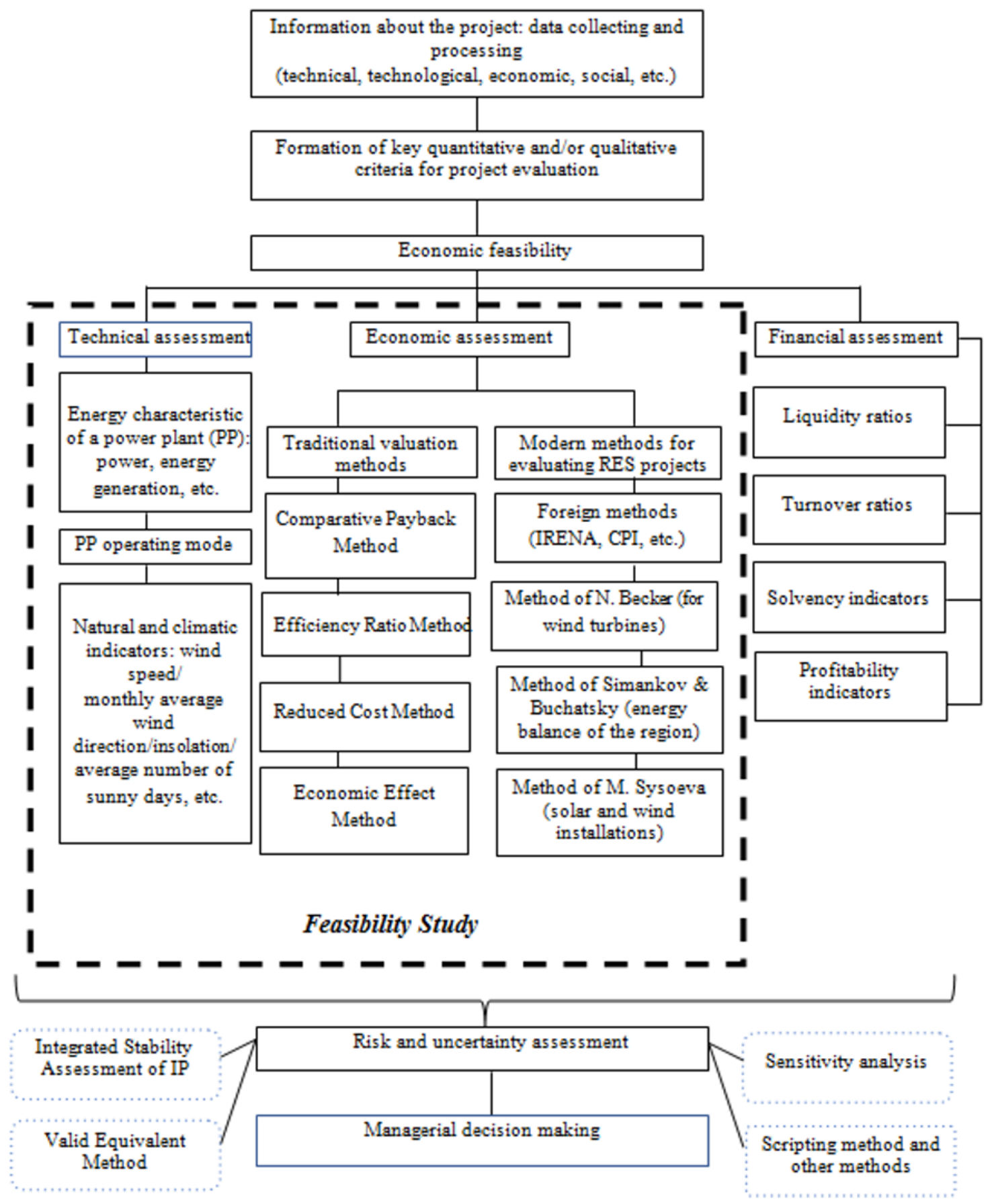

Fig. 1. Universal algorithm for assessing the economic efficiency of innovative-investment projects.

- Modeling of flows of products, resources and cash;

- Analysis of the impact of the project on business results and changes in the financial condition of the company;

- Accounting for the uncertainties and risks associated with the implementation of the project;

- Comparison of results and costs with an orientation towards achieving the required rate of return.

To implement these operations as part of the work on the algorithm, we analyzed a number of international and Russian methods for assessing the feasibility of implementing projects in the field of renewable energy.
In western countries, the practice of using renewable energy sources is much wider in comparison with that in the Russian Federation. Consequently, the experience in the field of determination of economic viability is also greater. In the EU and the USA various approaches to evaluate economic efficiency are offered by such organizations as: Climate Policy Initiative (CPI) [13], Alternative Energy Development (AED), The International Renewable Energy Agency (IRENA), etc. The techniques offered by them in most cases are based on the well-known "cost-benefit analysis" (CBA) (the analysis of expenses and benefits) which includes a set 
Table 1. Comparative analysis of the Russian assessment techniques for efficiency of RES introduction and usage.

\begin{tabular}{|c|c|c|c|}
\hline Author & Becker N.A. & Sysoeva M. S. & Simankov V.S., Buchatskiy P.U. \\
\hline $\begin{array}{l}\text { Type of renewable } \\
\text { power engineering } \\
\text { source }\end{array}$ & Wind energy & Sun and wind energy & The type of RES isn't specified \\
\hline Source & $\begin{array}{l}\text { Becker N.A. Assessment } \\
\text { of economic efficiency of } \\
\text { renewables' usage: on the } \\
\text { example of wind power of } \\
\text { Germany: Thesis for PhD } \\
\text { in economic sciences. } \\
\text { Moscow, 2007. }-127 \mathrm{p} \text {. }\end{array}$ & $\begin{array}{l}\text { Sysoyeva M.S. Improving } \\
\text { of the methodical device of } \\
\text { assessment of cost } \\
\text { efficiency of innovative and } \\
\text { investment projects of } \\
\text { introduction of alternate } \\
\text { sources of energy: Thesis } \\
\text { for PhD in economic } \\
\text { sciences. Tambov, 2011. } \\
144 \mathrm{p} \text {. }\end{array}$ & $\begin{array}{l}\text { Simankov V.S., Buchatskiy P.Yu. } \\
\text { Assessment of efficiency of } \\
\text { involvement of nonconventional } \\
\text { renewables in a regional energy } \\
\text { balance//Bulletin of the Adygei } \\
\text { state university. Series } 4 \text { : Natural } \\
\text { and mathematical and technical } \\
\text { sciences. - 2012. - No. } 2 .- \text { P. 1- } \\
10 \text {. }\end{array}$ \\
\hline $\begin{array}{l}\text { The main indicator } \mathrm{f} \\
\text { calculation }\end{array}$ & $\begin{array}{l}\text { Environmental } \\
\text { characteristics (average } \\
\text { wind speed; wind turbine } \\
\text { power; coefficient of wind } \\
\text { turbine power reduction; } \\
\text { availability of wind } \\
\text { turbine; coefficient of } \\
\text { change in air density, etc.); } \\
\text { Streams of benefits and } \\
\text { expenses; } \\
\text { The cash flows connected } \\
\text { with construction of wind } \\
\text { power plants (the } \\
\text { discounted cash flow, } \\
\text { cumulative cash flow). }\end{array}$ & $\begin{array}{l}\text { Capital investments for } \\
\text { installation of the chosen } \\
\text { generator; } \\
\text { Annual current expenses, } \\
\text { connected with introduction } \\
\text { of power stations; } \\
\text { Annual economic effect } \\
\text { from introduction of the } \\
\text { power station. }\end{array}$ & $\begin{array}{l}\text { The sum of complete expenses in } \\
\text { objects of RES (taking into } \\
\text { account inflationary processes, } \\
\text { discounting, use of credits, etc.); } \\
\text { The discounted social income of } \\
\text { the region; } \\
\text { Extra-power income; } \\
\text { The volume of tax receipts in the } \\
\text { budget of a region; } \\
\text { Volume of pollutions; } \\
\text { Effect from decrease in energy } \\
\text { deficiency, etc. }\end{array}$ \\
\hline & \multicolumn{3}{|c|}{$\begin{array}{l}\text { The net present value (NPV); } \\
\text { Internal rate of return (IRR); } \\
\text { The discounted payback period (DPP), and other traditional indicators of assessment of } \\
\text { investment projects. }\end{array}$} \\
\hline $\begin{array}{l}\text { Features of the } \\
\text { technique }\end{array}$ & $\begin{array}{l}\text { While assessing the RES } \\
\text { efficiency, a multicriteria } \\
\text { estimation is used, whicl } \\
\text { considers clean energy gail } \\
\text { and aspects of energy } \\
\text { security together with th } \\
\text { financial characteristics. Th } \\
\text { calculation of probabilisti } \\
\text { nature and technologica } \\
\text { special features of the proces } \\
\text { of production become } \\
\text { fundamental here. }\end{array}$ & $\begin{array}{l}\text { At the first stage the } \\
\text { developed technique allows } \\
\text { solving a problem of } \\
\text { assessment of annual } \\
\text { economic effect of } \\
\text { implementation of innovative } \\
\text { and investment projects of } \\
\text { introduction of power } \\
\text { stations (both in the modern } \\
\text { conditions, and for future } \\
\text { periods). sta } \\
\text { At the second stage the } \\
\text { system of additional } \\
\text { indicators on the basis of } \\
\text { cash flows taking into } \\
\text { account specific factors of a } \\
\text { solar and wind power } \\
\text { engineering is used for } \\
\text { implementing the complex } \\
\text { assessment of cost efficiency } \\
\text { of power stations } \\
\text { introduction along with } \\
\text { calculation of annual } \\
\text { economic effect. }\end{array}$ & $\begin{array}{l}\text { The integrated system of } \\
\text { criteria, which considers } \\
\text { expenditures for the creation } \\
\text { of the production base of } \\
\text { power engineering and makes } \\
\text { it possible to estimate the } \\
\text { efficiency of the use of } \\
\text { systems with the } \\
\text { nontraditional renewed } \\
\text { sources of energy (NVIE) in } \\
\text { the power system of region, } \\
\text { is proposed. The estimation } \\
\text { of the criteria in accordance } \\
\text { with the given procedure } \\
\text { presented is basis for } \\
\text { developing the optimization } \\
\text { model of involvement NVIE } \\
\text { in the energy balance of } \\
\text { region. Each criterion has its } \\
\text { system of indices. }\end{array}$ \\
\hline
\end{tabular}

of analytical tools used for assessment of financial and economic viability of the proposed project. Some of these analytical tools are listed below: 1) ratio of expenses and benefits; 2) net present value (or the discounted cash flow); 3) internal rate of return; 4) least total cost method; 5) payback period; 6) sensitivity analysis [14].

In general, the content of the above-mentioned methods of efficiency assessment abroad and in Russia do not differ significantly, i.e. the same indicators and formulas are used for calculations with which we got 
used to operate while evaluating investment projects (IP) in the Russian realities.

The American national noncommercial coalition of the public authorities and organizations, which work together for advancing the "pure" energy (Clean Energy States Alliance) suggests to study influence of RES projects on economy as part of cost-benefit analysis by means of one of the integrated modeling approaches realized via software IMPLAN, REMI, JEDI [15]. Models are developed on the basis of "input-output" model used in network programming. General principle of models' functioning works in the following way: the user working with the software product enters the required data on the considered project on implementation of installation on the basis of RES (location, commissioning date, number of turbines, size of turbines, investment and operating costs etc.), then the program estimates the annual economic influence on, for example, salary and productivity taking into account features of the region. Models are adapted only for the USA regions and can't be used for the analysis in other countries. Furthermore, this software is a commercial package.

The scientific team of Arif Malik, Mohammed Al Badi, Abdullah Al Kahali, Younis Al Nabhani, Alwarith Al Bahri Hamed Al Barhi (University n.a. the sultan Kabusa, Oman) propose to use a multicriteria approach to the assessment of projects in the field of renewable energy sources with the use of a system of decisionmaking support "Expert Choice" [16]. This system of decision making process is produced as a commercial product [17]. "Expert Choice" is based on the multicriteria decision making techniques called "Analytic hierarchy process" (AHP). The AHP is a powerful and flexible decision making process to help people set priorities and make the best decision when both qualitative and quantitative aspects of a decision need to be considered. The assessment and final prioritization of renewable energy alternatives is accomplished using the AHP software Expert Choice. The alternatives mentioned above are evaluated under different criteria. The selected criteria are technology and sustainability, economic, environmental, planning, and Government policy and regulations. With the exception of economic criterion the other criteria are evaluated under each alternative using experts' opinion. Further the program issues the solution basing on the expert estimations according to each of the criteria.

Also there is another approach, when the following blocks depending on the criteria are analyzed for the development of the expediency of implementation the project:

- Technical estimation (generation at a power plant, resource potential, the absorptive power of network, location etc.),

- Economic estimation (cost of equipment, production cost of $1 \mathrm{kWh}$, internal rate of return, net present value, payback period etc.),

- Ecological and social estimations (changes in the environmental conditions, visual pollution, the development of local economy, employment changes, an increase in the comfort of users and others) [18].

To evaluate each block, after the calculation of the specific indicators, score system (with values from 0 to 10 ) is used, each criterion is assigned a weight according to this technique. The matrix for decision making is compiled after the analysis of all blocks taking into account the obtained weights. This procedure is timeconsuming, and not all the proposed indicators can be calculated due to lack of information in modern Russian realities.

In this work we have also analyzed works of the following Russian researchers: Becker N.A., Sysoeva M. S., Simankov V.S., Buchatskiy P.U. These scientists propose their own modern methods, which are characterized by both general and various features.

Table 1 presents the comparative analysis of several Russian methods of assessment of efficiency of implementation and development of renewable energy sources. It is seen from this table that all methods are based on traditional assessment indicators (net present value, internal rate of return etc.). Also, all methods consider technological component of projects; however, there are differences in the set of indicators themselves.

The most suitable method for the purposes of our research is proposed by M. Sysoeva since her approach makes it possible to estimate efficiency independently of the type of the selected alternative energy source, unlike the technique of Becker N.A., which was developed only for wind power plants. The methodology proposed by Simankov V.S. and Buchatskiy P.Y. allows us to evaluate the efficiency of involving renewable energy sources in the energy balance of the region. As part of this study, we are aimed at a narrower scope, since we are considering the feasibility of involving RES in activities of a particular enterprise. In that case calculation of a number of indicators, such as, for example, the amount of tax revenues to the budget of the region, the discounted social income of the region and others, are insignificant for this study.

Thus, in our opinion the most suitable methodology to evaluate the efficiency of the innovative-investment project on implementation and development of renewable energy sources, namely, solar and wind energy, is provided by M. Sysoeva, and it can be applied within the framework of the algorithm proposed by the authors.

We should note that when calculating such projects it is important to pay special attention to environmental and social assessment, which undoubtedly is their competitive advantage in light of the latest trends in the development of the global economy. We also believe that the digital transformation of both the international and the Russian economy will give a powerful impetus to the development of the renewable energy market.

\section{References}

1. O.V. Marchenko, S.V. Solomin, Efficiency of hybrid renewable energy systems in Russia, Int. J. Of Renewable Energy Research, 1561-69 (2017) 
2. H.C. Teng, B.C. Kok, C. Uttraphan, M.H. Yee, A review on energy harvesting potential from living plants: future energy resource, Int. J. Of Renewable Energy Research, 2398-2414 (2018)

3. W. Stanek, T. Simla, W. Gazda, Exergetic and thermos-ecological assessment of heat pump supported by electricity from renewable sources, Renewable Energy, 131, 404-12 (2019)

4. T. Puksek, N. Duic, A. Foley, N. Markovska, Life cycle to pinch analysis and $100 \%$ renewable energy systems in a circular economy at sustainable development of energy, water and environment systems 2017, Renewable and Sustainable Energy Rev, 108, 572-7 (2019)

5. M. Sharifzadeh, A. Sikinioti-Lock, N. Shah, Machine-learning methods for integrated renewable power generation: a comparative study of artificial neural networks, support vector regression, and gaussian process regression, Renewable and Sustainable Energy Rev, 108, 513-38 (2019)

6. V. Campos-guzmán, M.S. García-Cáscales, A. Urbina, N. Espinosa, Life cycle analysis with multicriteria decision making: a review of approaches for the sustainability evaluation of renewable energy technologies, Renewable and Sustainable Energy Rev, 343-66 (2019)

7. A. Inayat, M. Raza, District cooling system via renewable energy sources: a review, Renewable and Sustainable Energy Rev, 360-373 (2019)

8. A.S. Abdulkareem, A.S. Afolabi, N. Fungura, T. Mokrani, C. Mateescu, The realities and economic benefit of the utilization of fuel cells as an alternative source of energy: a review Energy Sources. Part B, Economics, Planning, and Policy, 10, 404-11 (2015)

9. H. Karunathilake, K. Hewage, R. Sadiq, W. Mérida, Renewable energy selection for net-zero energy communities: life cycle based decision making under uncertainty, Renewable Energy, 130, 558-73 (2019)

10. F. Azeem, G.B. Narejo, U.A. Shah, Integration of renewable distributed generation with storage and demand side load management in rural islanded microgrid, Energy Efficiency (2018)

11. C. Scaramuzzino, G. Garegnani, P. Zambelli, Integrated approach for the identification of spatial patterns related to renewable energy potential in european territories, Renewable and Sustainable Energy Rev, 1-13 (2019)

12. I.S.M. Magasheva, D.A. Ilinykh, S.I. Ultan, The review of features of innovative-investment projects in the field of implementation and development of renewable energy sources and issues of evaluating their efficiency, Journal of Economy and entrepreneurship, 13, 1303-08 (2019)

13. A Comparative Case-Study Analysis of the Efficiency and Efficiency of Policies that Influence the Financing Renewable |Energy |Projects: |U.S. Iand |Europe I// ICPI [E-resource]. - Available at: http://www.usaee.org/usaee2011/submissions/Onlin eProceedings/Uday\%20Varadarajan $\% 20$ -
$\%$ 20USAEE $\% 20$ Online $\% 20$ Proceedings $\% 20$ \%202011-08-26.pdf

14. Alternative Energy Development Economic \& Financial Assessment of Renewable Energy Projects - Available at: http://pdf.usaid.gov/pdf_docs/Pnadb613.pdf

15. W. Leon, Evaluating renewable energy programs: a guide for program managers (CESA), 43 (2011)

16. A. Malik, M.A. Badi, A.A. Kahali, Y.A. Nabhani, A.A. Bahri, H.A. Barhi, Assessment of renewable energy projects using multi-criteria approach, IEEE 2014 Global Humanitarian Technology Conference, 350-355 (2014)

17. Expert Choice [E-resource]. - Available at: http://expertchoice.com

18. Methodology for Evaluating Renewable Energy Projects // Fundación Chile - BID Fomin [Eresource]. - Available at: http://www.fch.cl/wpcontent/uploads/2012/10/8 -

_Methodology_for_Evaluating_Renewable_Energy _Projects.pdf 